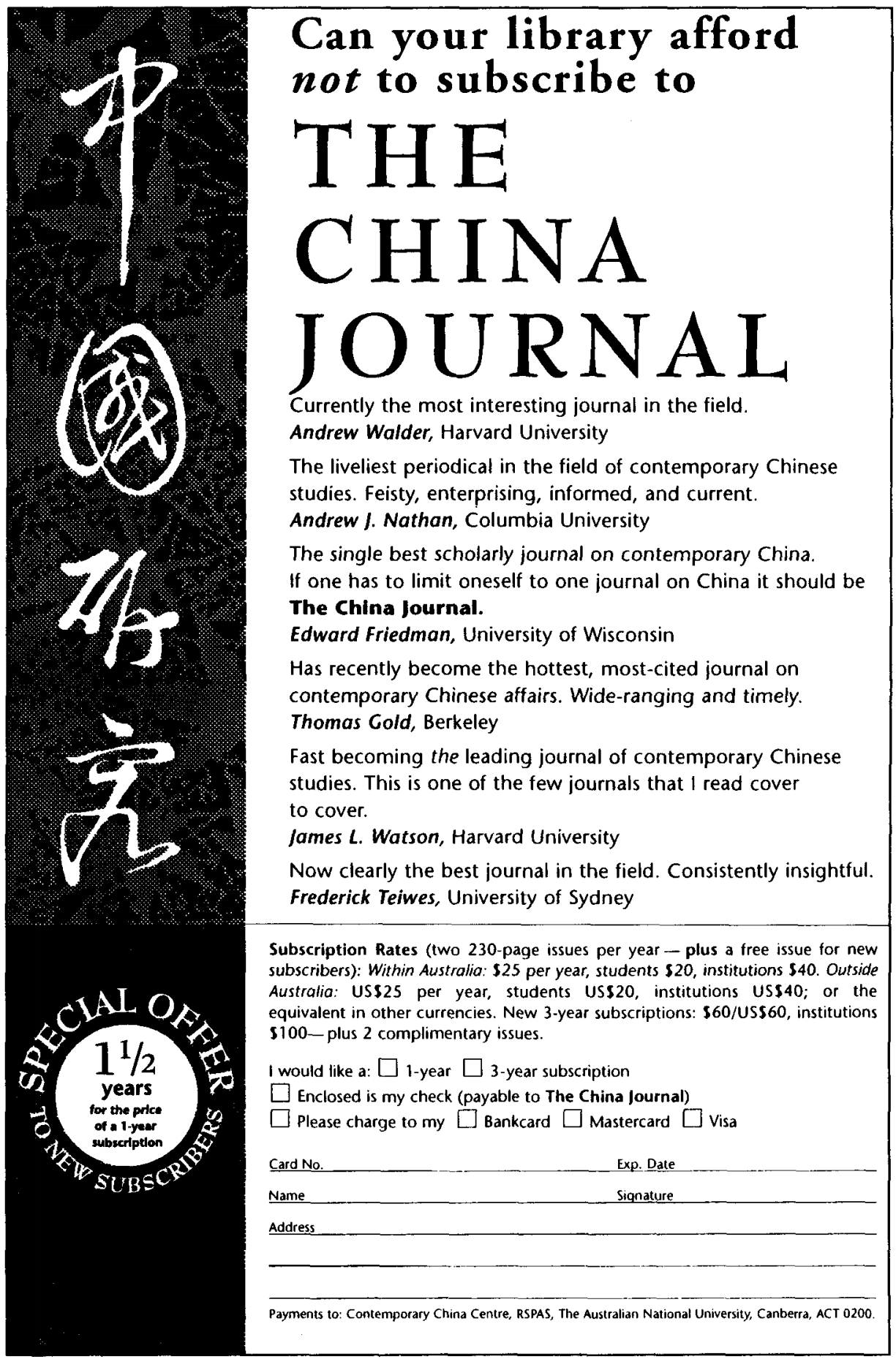




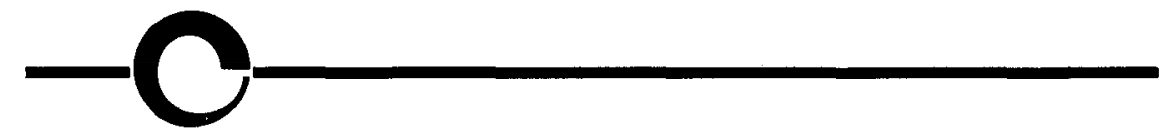

Institutional Designs for a Complex World

Bargaining, Linkages, and Nesting

EDITED BY

VINOD K. AGGARWAL

"A perceptive theoretical analysis of the politics of coordination within and among international institutions. The book includes richly detailed case studies of the politics of institutional design, innovation, and coordination involving several major European and Euro-American financial, trade, and military institutions."-Joseph M. Grieco, Duke University. 4 tables, 24 graphs. $\$ 45.00$ cloth, $\$ 17.95$ paper

\section{Beyond Appeasement} Interpreting Interwar Peace Movements in World Politics CECELIA LYNCH

Histories have held that interwar peace movements have been ineffective, and that they weakened national efforts to resist Nazi Germany and Stalinist Russia. Cecelia Lynch challenges these interpretations. Focusing on the construction of the United Nations, Lynch brings to light the role of social movements in its formation. "[F]ascinating."-Nigel Young, Colgate University $\$ 32.50$

\section{The Cultural Dynamics of Democratization in Spain}

PETER MCDONOUGH, SAMUEL H. BARNES, and $A N T O N I O$

LÓPEZ-PINA

This book examines Spain's transition to democracy. Drawing on national surveys, the authors ask: What is the basis of the new regime's political legitimacy? How did Spanish democracy move from the conservative centerright coalition that engineered the transition to the socialist government that consolidated it? And why is political participation so low? 34 tables, 38 charts/graphs $\$ 39.95$

\section{State Building and Late Development}

\section{DAVID WALDNER}

Why does state building sometimes promote economic growth and in other cases impede it? Through an analysis of political and economic development in four countries-Turkey, Syria, Korea, and Taiwan-this book explores the origins of political-economic institutions and the mechanisms connecting them to economic outcomes. 1 chart/ graph. \$49.95 cloth, $\$ 18.95$ paper

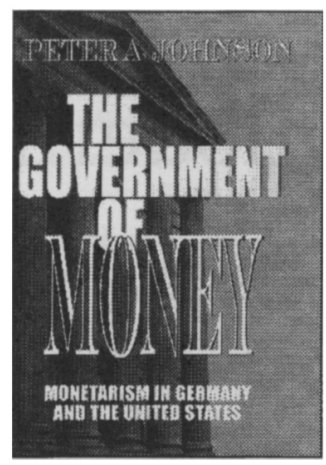

The

Government of Money

Monetarism in Germany and the United States

PETER A. JOHNSON

In recent years, governments have increasingly given their central banks the freedom to pursue policies of price stability. In particular, the German Bundesbank and the U.S. Federal Reserve have been widely considered models of autonomous policymaking. This book traces the origins of their success to the political struggle to adopt monetarism in Germany and the United States. Cornell Studies IN Political EConomy. $\$ 39.95$

AT BOOKSTORES, OR CALL (607) 277-2211

VISIT OUR WEBSITE unw.cornellpress.cornell.edu

\section{$\begin{array}{llllllllllllllllllllll}C & O & R & N & E & L & L & U & N & \text { I } & V & E & R & S & \text { I } & T & Y & P & R & E & S & S\end{array}$}




\section{"the leading interdisciplinary journal on modern China"}

Nicholas LaRdY, THE BroOKINOS ImStmUTION

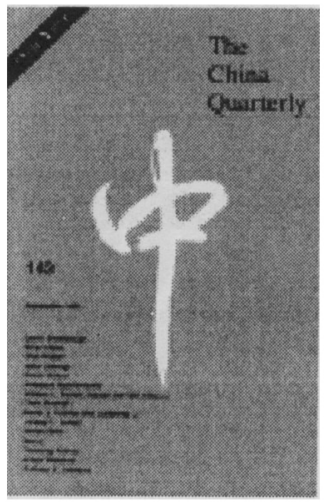

\section{The China Quarterly}

EDTED or Richand LOUIS EDMondos

The China Quarterly is the leading interdisciplinary journal on the People's Republic of China, the Hong Kong SAR, Macau and Taiwan. Covering everything from politics and international affairs, economics and commerce, geography and demography through to art and literature you can guarantee the quality of the contributors and the inestimable value of their contributions.

\section{KEEP UP TO DATE}

Oxford Universily Press is pleased to announce its new lable of contents e-mail service. You can join this whather you are a subscriber or not. To regularly receive the very latest table of contents - in odvance of publication - just go to the web addresses below and follow the simple instructions.

www.oup.co.ukJchinaq

\section{Special issue: People's Republic of China at $\mathbf{5 0}$}

This issue will attempt to objectively assess and sum up change and major trends in the People's Republic of China since 1949, with an emphasis on developments in the last 10 years. The issue will have an overview by Lucian Pye and contains articles by Michael Schoenhals on The Party and Political Movements, John P. Burns on National Political Reform, Jean C. Oi on Rural Reform, Dorothy Solinger on Urban Economic Reform, Richard Louis Edmonds on Environment, Energy and Transport, Robert Dernberger on the Macoeconomic Situation, Michael Yatuda on Foreign Relations, David Shambaugh on The Miltary, Pitman B. Potter on The Legal System, Elisabeth Croll on Social Welfare, Merle Goldman on intellectuals and Students, Bonnie S. McDougall on Literature, and Michael Sullivan on Art.

\section{The Gordon White Prize}

The China Quarterly is pleased to announce the inauguration of this new academic prize in memory of Professor Gordon White. The prize will be awarded annually for the most original article or research note published in the journal in the relevant year. The value of the prize is $\{500$.

All enquiries and submissions should be directed to:

Joanne Phillips, The China Quarterly, School of Oriental and African Studies, University of London, Thornhaugh Street, Russell Square London WC1H OXG,

Email: chinaq@soas.ac.uk

Order a free sample copy

$\square$ Please send me a free sample copy of The China Quarterly

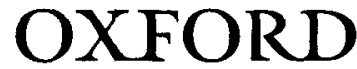

UNIVERSITY PRESS
Name (PLEASE PGINT)

Address

Zip Country

For further details contact Journals Marketing (XAD) Oxford University Press 2001 Evans Road, Cary, NC 27513 tel : 18008527323 usA c Canada onty) or 9196770977 fax: 9196771714 


\section{Contesting Citizenship in Urban China}

Peasant Migrants, the State, and the Logic of the Market

Dorothy J. Solinger

"An outstanding work. Solinger's comprehensive treatment is likely to gain immediate attention."

-Elizabeth Perry, author of Shanghai on Strike

$\$ 50.00$ cloth, $\$ 19.95$ paper

\section{Rural China Takes Off}

The Institutional Foundations of Economic Reform

Jean C. Oi

"Rural China Takes Off is both empirically rich and theoretically profound."

-Lucian W. Pye, Massachusetts Institute of Technology

$\$ 35.00$ cloth, $\$ 17.95$ paper

\section{Bicycle Citizens}

The Political World of the

Japanese Housewife

Robin M. LeBlanc

Foreword by Saskia Sassen

"A gem of a book. LeBlanc brings

the women she studies to life."

-Glenda Roberts, author of Staying on the Line

A Study of the East Asian Institute,

Columbia University

Asia: Local Studies/Global Themes

$\$ 40.00$ cloth, $\$ 14.95$ paper

At bookstores or order 1-800-822-6657

\section{University of California Press}

www ucpless edu

\section{Fault Lines}

Journeys into the

New South Africa

David Goodman

Photographs by Paul Weinberg

"This is a searingly honest book by someone who really knows his subject."-Archbishop Desmond Tutu

Perspectives on Southern Africa

$\$ 29.95$ cloth, illustrated

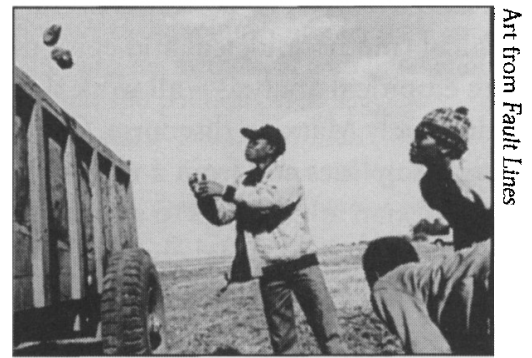

\section{Between Memory and Desire}

The Middle East in a Troubled Age R. Stephen Humphreys

"An outstanding piece of work on the relationship between secular and religious politics in the Middle East. ...His integration of early Islamic and contemporary history is novel, bold, and successful." - Leila Fawaz, author of An Occasion for War $\$ 29.95$ cloth

New in Paperback

The Snow Lion and the Dragon

China, Tibet, and

the Dalai Lama

Melvyn C. Goldstein

"A rigorously unsentimental

account."-New York Review of Books

$\$ 13.95$ paper, illustrated 


\section{Rethinking

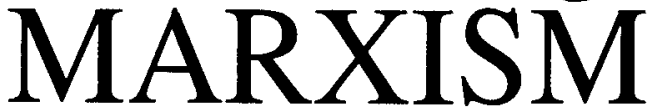

A Journal of Economics, Culture, and Society

The aim of the journal is to stimulate interest and debate over the explanatory power and social consequences of Marxian economic and social analysis. To that end, it publishes studies that seek to discuss, elaborate, and/or extend Marxian theory. The concerns of the journal include theoretical and philosophical (methodological and epistemological) matters as well as more concrete empirical analysis - all work that leads to the further development of a distinctively Marxian discourse. Contributions are encouraged from people in many disciplines and from a wide range of perspectives. It is the editors' belief that Marxian approaches to social theory are important for developing strategies toward radical social change-in particular, for ending class exploitation and the various forms of political, cultural, and psychological oppression including oppression based on race and gender. Research that explores these and related issues from a Marxian perspective are particularly welcome.

ARTICLES OF INTEREST: Marx, Fanon, Nkrumah, and the Intersection of Socialism and Radical Feminism, Kenneth Long $\bullet$ Marxist Theory and Marxism as a Mass Ideology: The Effects of the Collapse of 'Really Existing Socialism' to West-European Marxism, John Milios - Throwing a Dishcloth into the Works: Troubling Theories of Domestic Labor, Jenny Cameron Art, Economy, and the Differentiation of Value, Roby Rajan

\section{SUBSCRIPTION INFORMATION}

ISSN 0893-5696, Volume 10, 1998 (4 issues)

Individuals: $\$ 33.00$; Outside U.S.: $\$ 45.00$ (surface mail); $\$ 55.00$ (airmail) Institutions: $\$ 95.00$; Outside U.S.: $\$ 117.00$ (airmail) Students*: $\$ 20.00$; Outside U.S.: $\$ 27.00$ (surface mail); $\$ 37.00$ (airmail) *Current I.D. required.

Also available in better bookstores.

GUILFORD PUBLICATIONS, INC., Attn: Journals Dept.

72 Spring Street, New York, NY 10012

Call Toll-Free: 1-800-365-7006, 9 AM to 5 PM EST

CALL: 212-431-9800 • FAX: 212.966-6708

E-mail: staff@guilford.com

Website: http://www.guilford.com

SAMPLE COPIES AVAILABLE! samples@guilford.com 


\section{THE BEST IN WORLD POLITICS}

\section{Statecraft and Security}

The Cold War and Beyond

Ken Booth, Editor

The contributors of this book examine the lessons and legacies of the Cold War, the key powers and their policies in the postCold War world, and changing ideas about human society at a time of transformation.

Contributors: Ken Booth, Raymond L. Garthoff, Richard Ned Lebow, Janice Gross Stein, Michael Clarke, Donald Daniel, Cori Dauber, Michael Herman, John McDonnell, John Steinbrunner, Oles M. Smolansky, Karen Dawisha, Catherine McArdle Kelleber, Robert O'Neill, Geoffrey Hawthorn, Michael Cox, Denis Stairs, Barry M. Blechman, Antbony Giddens, Philip Allott

0-521-47453-1 Hardback \$59.95

0-521-47977-0 Paperback \$19.95

\section{Zionism and the Foundations of Israeli Diplomacy Sasson Sofer}

The book traces the development of Zionist ideology in the years prior to Israel's independence. The analysis demonstrates how the political, social and economic foundations of the future state were negotiated in this period and how these ideologies have endured and are reflected in present-day Israeli diplomacy and in the fragmentary nature of its politics.

0-521-63012-6 Hardback \$64.95

\section{Shrinking the State}

The Political Underpinnings

of Privatization

\section{Harvey Feigenbaum,}

\section{Chris Mamnett and Jeffrey Henig}

This book provides a comparative political analysis of privatization in the UK, United States and France. The authors argue that privatization is a political phenomenon and should be analyzed as such, rather than as an economic response to the growth of the state and the cost of state provision.
$0-521-63080-0$
Hardback
$\$ 54.95$
$0-521-63918-2$

Problem Representation in Foreign Policy Decision Making Donald A. Sylvan and James F. Voss, Editors

Previous studies of foreign policy decision making have largely focused on the choice among specified options rather than the prior question of how the options were specified in the first place. Such "problem representation" is the focus of this volume. The contributors to the volume consider these issues, employing the methods of both international relations and political psychology.

Contributors: Donald A. Sylvan, James $F$. Voss, Charles S. Taber, Robert Billings, Charles F. Hermann, Ryan Beasley, Martha Cottam, Dorcas E. McCoy, Helen Purkitt, Deborah M. Haddad, Michael Young, Katherine Gannon, Silvana Rubino-Hallman, Jennifer Wiley, Joel Kennet, Tonya Schooler, Laurie Ney Silfies, Marijke Breuning

0-521-62293-X Hardback \$59.95

\section{Security Communities \\ Emanuel Adler and \\ Michael Barnett, Editors}

This book argues that community can exist at the international level, and that states dwelling within an international community have the capacity to develop a pacific disposition.

Contributors: Emanuel Adler, Michael Barnett, Ole Waever, Gregory A. Gaus III, Amitav Acharya, Richard A. Higgott, Kim Richard Nossal, Andrew Hurrell, Guadelupe Gonzalez, Stephen Haggard, Sean Shore, Bruce Russett, Charles Tilly Cambridge Studies in International Relations 62 0-521-63051-7 Hardback \$69.95 0-521-63953-0 Paperback \$24.95

Available in bookstores or from CAMBRIDGE UNIVERSITY PRESS

40 West 20th St., N.Y., NY 10011-4211 Call toll-free 800-872-7423.

Web site: http://www.cup.org MasterCard/VISA accepted. Prices subject to change. 


\section{International Social Science Journal}

\section{Edited by David Makinson}

The International Social Science Journal bridges communities of social scientists between disciplines, and between different parts of the globe. It is truly interdisciplinary and international, diffusing information and debate to the widest possible audience. The principal section of each issue is devoted to a general theme of current interest while other sections cover continuing debate on themes of preceding issues, professional matters of the social sciences, and an open forum. ISSJ is available in six languages (English, French, Spanish, Arabic, Chinese, Russian).

\section{Recent Issues}

152: Democracy and Law

153: Anthropology - Issues and Perspectives I: Transgressing Old Boundaries 154: Anthropology - Issues and Perspectives II - Sounding Out New Possibilities 155: Governance

156: Social Transformations: Multicultural and Multi-ethnic Societies 157: Fifty Years of the ISSJ: A Selection of Articles (including contributions by Paul van Morpurgo, Claude Levi-Strauss, Simon Kuznets. Jan Tinbergen, Philippe Perier, Paul Lazarsfeld, Maria Hirszowicz, Ignacy Sachs, Peter Lengyel, Petter Willmott, Sarvepalli Gopal, Awa Thiam, Aderanti Adepoju, Ali Kazancigil, Johan Galtung, Luo Yuanzheng, Elisa P. Reis, Rodolfo Stavenhangen, Roberta Balstad Miller, Federico Mayor)

International Social Science Journal ISSN 0020-8701 Published in.March, June, September and December

Subscription Rates, Vol. 51/1999:

Institutions: Europe $£ 72, \mathrm{~N}$. America $\$ 155$, Developing World £39, Rest of World £94.

Personal: Europe £36, N. America \$76, Rest of World £46.

To subscribe to International Social Science Journal please use the order form on the Blackwell website: $h t t p: / / w w w . b l a c k w e l l p u b l i s h e r s . c o . u k$, send an email to jnlinfo@blackwellpublishers.co.uk, or contact either of the following:

- Blackwell Publishers Journals, PO Box 805, 108 Cowley Road, Oxford OX4 1FH, UK Tel: +44 (0)1865 244083, fax +44 (0)1865 381381

- Journals Marketing (ISSJ), Blackwell Publishers, 350 Main Street, Malden, MA 02148, USA. Tel. +1 (781) 3888200 , fax +1 (781) 3888210

\section{SPECIAL OFFER for 1999

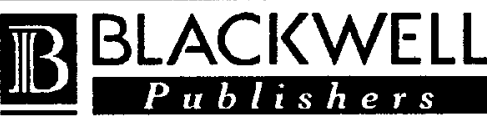

Electronic access included in the institutional subscription price to the print edition

For more information visit our website 


\section{A Selection of (Outstanding Politics Journals from SACE Publications...}

\section{Cooperation and Conflict}

\section{Editor Iver B Neumann}

...reflects the vitality and diversity of contemporary Scandinavian international relations research and addresses vital issues in the scholarly search for a better grasp on the complexities of world affairs.

Quarterly: ISSN 0010-8367. Individual Rate $£ 37$. Institutional Rate $£ 144$

\section{European Journal of International Relations}

\section{Editor Walter Carlsnaes}

...stimulates and disseminates the latest research in international relations.

Quarterly: ISSN 1354-0661.

Introductory Rate for Individuals $£ 30$.

Institutional Rate $\$ 156$

\section{International Political Science Review}

\section{Editors Nazli Choucri and Jean}

Laponce

...creates and disseminates rigorous political inquiry reflecting the latest research being undertaken on the central and currently controversial themes of the discipline.

Quarterly: ISSN 0192-5121. Individual

Rate $£ 47$. Institutional Rate $\$ 115$

\section{Journal of Peace Research}

Editor Nils Petter Gleditsch

...publishes scholarly work in peace research concentrating on the causes of violence, methods of conflict resolution and ways of sustaining peace.

Bimonthly: ISSN 0022-3433.

Introductory Rate for Individuals $\$ 43$ Institutional Rate $£ 204$

\section{Party Politics}

Editors David M Farrell, Ian Holliday and Kenneth Janda

...provides an important forum for discussion of historical development, policy, ideology, electoral programmes, changing party systems and the democratic process.

Quarterly: ISSN 1354-0688

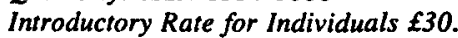

Institutional Rate $£ 156$

\section{Security Dialogue}

\section{Editors Pavel Baev and Anthony McDermott}

...provokes reflection through interregional dialogue on issues of global security addressing the new international system, politics of fusion and fragmentation, as well as military, political, economic and environmental aspects of security.

Quarterly: ISSN 0967-0106.

Introductory Rate for Individuals $£ 28$. Institutional Rate $£ 128$

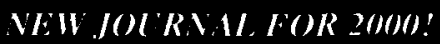

\section{European Union Politics}

Executive Editor Gerald Schneider ...is a new international journal which advances systematic research on the most important political processes and institutions of the European Union.

Triannual: First issue February 2000. ISSN 1465-1165. Introductory Rate for Individuals $£ 24$. Institutional Rate $£ 120$ 


\section{DEVELOPING DEMOCRACY}

\section{TOWARD CONSOLIDATION}

\section{Larry Diamond}

CSA splendid tour de force. Diamond commands and skillfully organizes an amazing amount of knowledge and information, while at the same time discussing, in a subtle and penetrating but also very readable manner, the complex theoretical issues raised by processes of democratization, East and South. Clearly, this book is the product not only of great talent and dedication but also of deep personal commitment to the humane values that, as Diamond persuasively argues, undergird the emergence and the expansion of democracy.99

\section{-Guillermo O'Donnell}

C6Larry Diamond has built a cumulative record of outstanding scholarship on democracy. This book flows logically from his earlier contributions. It illuminates brilliantly the problems and opportunities of emerging democracies, especially the critical phase of democratic consolidation. In a world struggling to find ways of establishing durable democracies, this book is at once a timely and fundamental contribution.s9

-David A. Hamburg, M.D., President Emeritus, Carnegie Corporation of New York
65Larry Diamond has written the authoritative book on the democratic experience-lucid and discriminating in its theoretical grasp, and masterful in its presentation of evidence.99

\section{-Gabriel A. Almond}

65 Developing Democracy is for our time the definitive assessment of the third wave of democratization that began in 1974. It is comprehensive in its research, penetrating in its analysis, and balanced in its judgments.

Diamond highlights both the progress that has been made and yet the extent to which so many new democracies are illiberal 'hollow democracies.' Making full use of the recent immense literature on democratization, he persuasively analyzes the impact of economic growth, decentralization, political culture, and civil society on the prospects for the consolidation of third wave democracies and for a fourth wave of democratic development.s9

\section{-Samuel P. Huntington}

$\$ 49.95$ hardcover $\$ 17.95$ paperback 


\section{LYNNE RIENNER PUBLISHERS}

The Self-Restraining State:

Power and Accountability in New Democracies edited by Andreas Schedler, Larry Diamond, and Marc F. Plattner

hc $\$ 59.95 / \mathrm{pb} \$ 24.95$

\section{Selling Globalization:}

\section{The Myth of the Global Economy}

Michael Veseth

"A perfect introduction to change in the global economy that also dissipates the rhetorical fog surrounding the issue."

-Herman Schwartz

hc $\$ 45$

\section{Understanding Contemporary China} edited by Robert E. Gamer

hc $\$ 55 / p b \$ 22$

\section{Political Liberalization and}

\section{Democratization in the Arab World:}

Vol. 2, Comparative Experiences

Bahgat Korany, Rex Brynen, and Paul Noble

"Provides a comprehensive survey ... and makes a major contribution to constructing theories about transitions to democracy."-Tansa George Massoud hc $\$ 55 / p b \$ 22$

\section{U.S. Politics and the Global Economy: Corporate Power, Conservative Shift Ronald W. Cox and Daniel Skidmore-Hess $h c \$ 49.95$}

\section{Fernando Henrique Cardoso:} Reinventing Democracy in Brazil

Ted G. Goertzel

“Goertzel's engaging account of Cardoso's intellectual and political trajectory provides an important baseline from which to explore both recent Brazilian history and one of the most exciting leaders in twentieth century Latin America."

-Mauricio Font

March 1999 / hc $\$ 49.95 / \mathrm{pb} \$ 19.95$
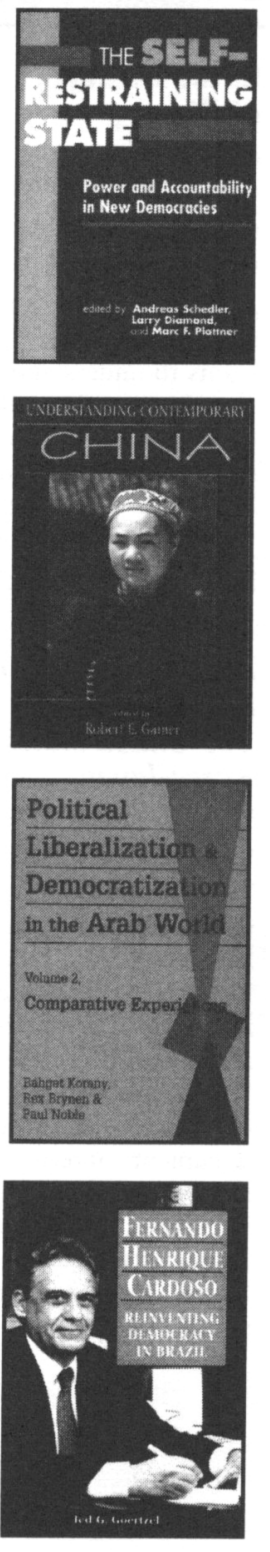

CILEBRIING 15 YIARSOF INDEPFNIIENT PUBIISHING 


\section{Global Thinking}

\section{In the Stream \\ of History}

Shaping Foreign

Policy for a New Era

WARREN

CHRISTOPHER

"A first-rate historical document. ... Anybody who wants to understand American foreign policy from 1993 to 1997 needs to consult In the Stream of History." -Washington Post Book World

$\$ 22.95$ paper $\$ 60.00$ cloth

\section{Alignment Despite Antagonism \\ The United States- \\ Korea-Japan \\ Security Triangle \\ VICTOR D. CHA}

The first in-depth study of the puzzling relationship between Japan and the Republic of Korea and the influence of the United States on it from the Cold War to the present. It draws on recently declassified U.S. documents, internal Korean government documents, and interviews with former policy makers in the United States, Japan, and Korea. $\$ 49.50$ cloth

\section{The Evolution} of Inequality

War, State Survival, and Democracy in Comparative Perspective

MANUS I. MIDLARSKY

This book studies the structural inequalities between states as they evolve and influence the political process. It analyzes various forms of political violence, including war and revolution, the origins and dissolution of states, and the sources of cooperation between states. The ultimate genesis of democracy is shown to be a consequence of the processes detailed in the book.

$\$ 45.00$ cloth

\section{Conversations with Anthony Giddens Making Sense of Modernity

ANTHONY GIDDENS
\& CHRISTOPHER
PIERSON

These interviews of one of the leading social theorists of the contemporary period, conducted shortly after he became Director of the London School of Economics and Political Science, cover the full range of his thought since the early 1970's.

$\$ 16.95$ paper $\$ 45.00$ cloth
Re-lmagining Political Community Studies in Cosmopolitan Democracy

Edited by

DANIELE ARCHIBUGI, DAVID HELD，\& MARTIN KÖHLER

"Extending democracy beyond borders is what I advocated throughout my mandate at the UN. This fascinating book tells us that while transnational democracy is still a utopian fantasy, it may be the reality of tomorrow."

-Boutros Boutros-Ghali,

Former Secretary-General of the United Nations

$\$ 22.95$ paper $\$ 60.00$ cloth

\section{Civil Society \\ Old Images, \\ New Visions \\ JOHN KEANE}

John Keane explores previously uncharted intellectual territory, demonstrating that new images of civil society can alter the way we think about matters such as power, property, violence, politics, and democracy. $\mathrm{He}$ suggests that the formation of civil society may be the best antidote to the worldwide problems of nationalism.

$\$ 16.95$ paper $\$ 45.00$ cloth 
EAST-West CENTER SERIES

Political Legitimacy in Southeast Asia

\section{The Quest for}

Moral Authority

$\overline{\text { Edited by }}$

MUTHIAH ALAGAPPA

The countries of Southeast

Asia have had varying

degrees of success in estab-

lishing governments that are perceived by their citizens to have the right to rule. This book analyzes variations in political legitimacy in Malaysia, Singapore, Philippines, Burma, Thailand, Indonesia, and Vietnam to present specific conclusions on Southeast Asia and the relevance of the framework for the study of political legitimation in other countries.

$\$ 24.95$ paper $\$ 65.00$ cloth

\section{Deepening}

\section{Democracy?}

The Modern Left and Social Movements in Chile and Peru

\section{KENNETH M. \\ ROBERTS}

"This is an excellent study of the plight of the left in Latin America in the post-Cold War era of neoliberalism. The theoretical framework is very insightful, resting on clear concepts and thinking. Moreover, Roberts's country cases are well chosen-one of the most successful leftist experiences (Chile) versus one of the least successful." -Choice $\$ 19.95$ paper $\$ 55.00$ cloth
The Life and Times of Pancho Villa

FRIEDRICH KATZ

"A towering biography. . . . The research here obviously represents decades of devotion, and it is formidable.

.. . A broader perspective on the revolution, one that is sorely needed."

-New York Times Book Review

$\$ 29.95$ paper $\$ 85.00$ cloth

\section{New and Old Wars Organized Violence in a Global Era}

\section{MARY KALDOR}

"More than any other book, Mary Kaldor's brilliantly sustained enquiry into 'new wars' helps us grasp the complex terrain of political violence since the end of the Cold War. The richness and clarity of the overall presentation greatly strengthen Kaldor's stature as one of the most consistently imaginative and conceptually creative thinkers of our time on the central issues of global affairs." -Richard Falk, Princeton University $\$ 16.95$ paper $\$ 45.00$ cloth

\section{Global} Transformations Politics, Economics, and Culture

By DAVID HELD \&

ANTHONY MCGREW, DAVID GOLDBLATT \& JONATHAN PERRATON

"This book is a superb and extraordinary accomplishment, one that is destined to become the definitive work on globalization for a long time to come. It is both a succinct summary of a vast field and a creative synthesis ... so fully coherent as to break new ground in remarkably imaginative and disciplined ways."

-James N. Rosenau, George Washington University

$\$ 29.95$ paper $\$ 75.00$ cloth

Visit our Web site for more information and to request our new International Relations \& Political Science catalog. 


\section{New in Paperback}

IMAGINING

Imagining War

French and British Military Doctrine between the Wars

\section{Elizabeth Kier}

In Imagining War, Elizabeth Kier takes issue with the conventional wisdom that military organizations inherently prefer offensive doctrines. Kier argues that a military's culture affects its choices between offensive and defensive military doctrines.

"Kier's book is a welcome and important addition to the growing body of literature concerned with doctrine. The high quality of her work reflects not only a keen understanding of the of the doctrinal process but also a willingness to investigate the archival materials essential for such an understanding."-Robert A. Doughty, American Political Science Review

Princeton Studies in International History and Politics: Paper \$17,95 ISBN 0-691-00531-1

\section{Open-Economy Politics}

The Political Economy of the World Coffee Trade

\section{Robert H. Bates}

Coffee is traded in one of the few international markets ever subject to effective political regulation. Here Robert Bates explores the International Coffee Organization, an international "government of coffee" that was formed in the 1960 s.

"Bates's approach is ... innovative. ... The book is beautifully produced, full of useful data. ... . It will provoke lively debate."-Robert G. Greenhill, Economic History Review

Paper \$17.95 ISBN 0-691-00519-2

\section{Princeton University Press}

AT FINE BOOKSTORES OR CALL 800-777-4726・HTTP: //PUP.PRINCETON.EDU 